\title{
MIELIKUVAMAAILMASSA TEORIASSA JA HARJOITUKSIN
}

\author{
Raimo Lind (1998) \\ Mielikuvaoppiminen, \\ Juva: WSOY, 206 sivua
}

\section{Raimo Lindh toivottaa kirjansa loppusanoissa mieli- kuvaoppimisen uuden vuosi- tuhannen tervetulleeksi. Mah- tipontisten loppusanojen lu- paukseen uskoo virtuaalito- dellisuuden kynnyksellä ken tahtoo. Lindhillä on kuiten- kin painavaa sanottavaa ja kir- jaan kannattaa tutustua. Se saattaa myös innostaa kokeile- maan siinä olevia ajatuksia ja harjoituksia.}

Kirja alkaa mielen ja tietoisuuden käsittelyllä. Heti alusta asti mieli ja tietoisuus nivotaan fysiologisesti ja biologisesti painottaen aivojen ja keskushermoston toimintaan. Kirja alkaa pyrkimyksellä ylittää cartesiolainen dualismi eli jaottelu objektin ja subjektin välillä. Tätä ylitystä pyritään kuitenkin tekemään lähes yksinomaan fysiologian, biologian ja fysiikan objektivoivilla näkemyksillä.

Lindh ei esittele psykodynamiikkaa eikä sosiaalista konstruktivismia, vaikka puhuukin mielestä. Näin cartesiolaisen dualismin ylitys jää pikemminkin lupaukseksi vailla katetta, kuin todella toimivaksi käytännöksi. Mieli on varmasti muutakin kuin keskushermoston ja aivojen toiminta. Tilannetta ei auta se, että niiden toiminta kytkettäisiin monimutkaiseen teoriaan, kuten kvanttiteoriaan.

\section{Lindh havainnollistaa} osuvasti kirjaansa harjoituksilla, joita lukija voi itse kokeilla. Harjoitukset ovat kiinnostava ja antoisa osa kirjaa. Harjoitukset on kuitenkin kirjan alkuosassa kytketty fysiologisesti, biologisesti ja fysiikallisesti painottuneeseen teoriaan. Niinpä esimerkiksi aaltofunktioiden katkeamisen tai muistihologrammin löytäminen kirjassa esitettyjen harjoitusten avulla todentaa pikemmin maailman sosiaalisesti konstruoituneen luonteen kuin ajattelun kvanttiluonteen. Nimittäin jos lukija on 
ensin lukenut kvanttiteoriaa ja sitten hänelle esitetään harjoituksia sen soveltamisesta omaan kokemusmaailmaan, ollaan jo luotu symboliympäristö, jonka sisällä harjoitus ja siihen liittyvät mielikuvat kulkevat. Lukija on tällöin kirjan tekstuaalisuuden sisällä, eikä ole neutraalissa ympäristössä tarkastelemassa "omia" kokemuksiaan, vaan luomassa sisäistä puhetta ja tulkintaa suhteessa kirjan tekstiin. On todennäköistä, että lukija luulee harjoitusten avulla todentaneensa mielikuvien kvanttiluonteen, mutta onkin todellisuudessa joutunut kirjan sanojen vangiksi.

\section{Cartesiolaisen dualismin} mukaisesti kirjassa puhutaan minästä, jolla on asenteita ja luonne. Kirja hahmottaa minän rakentuvan osin geneettisen koodin, osin jopa kehityshistoriallisten kaikujen varaan. Tältä osaltaan kirjan välittämä ihmiskuva on vanhahtava ja korostaa liiaksi minän yhtenevää ja kiinteää luonnetta. Psykologiassa on jo pitkään puhuttu minän rakenteen sijasta itsestä, joka nähdään pikemmin objektisuhteissa ja sosiaalisissa konteksteissa tuotettuna, kuin kiinteänä rakenteena. Lisäksi sosiaalipsykologia ja kriittinen psykologia ovat viime aikoina osoittaneet ihmisen ajattelun ja puheen vaihtelevuuden ja ristiriitaisuuden eri tilanteissa sekä jopa samoissa tilanteissa. Nämä näkökulmat olisi ollut hyvä tuoda esille kirjassa, sillä ne olisivat mahdollistaneet mielikuvaoppimiselle myönteisen ihmisen jatkuvan muuttumisen tarkastelun.

Kirjan parasta antia on mielikuvaoppimiseen liittyvä teoria ja harjoitukset. Lindh painottaa rentouden ja turvallisuuden merkitystä oppimiskokemukselle. Tämä painotus on varmasti oikeaan osunut. Hän painottaa myös huippukokemusten ja virtaavan tilan saavuttamisen mahdollistumista rentoutumisen ja turvallisen tilan sekä leikillisyyden ilmapiirin vallitessa.

\section{Voi hyvin uskoa}

oppimisen tehostuvan rentoutusharjoituksen jälkeen tehdyissä harjoituksissa, joissa taustalla soi sopiva musiikki. Voi myös uskoa miellyttävien mielikuvien liittämisen oppimistapahtumaan parantavan oppimistulosta. Näitä asioita käsittelevät kirjan osat ovat kiinnostavia ja antoisia.

\section{Antoisa on myös kirjan}

loppuosa, jossa mielikuvaoppiminen yhdistetään NLP:hen (neurolingvistinen ohjelmointi). Tässä jaksossa Lindh esittelee lyhyesti NLP:tä ja tuo esille mielikuvaoppimisen avulla saatuja tuloksia. Mielikuvaoppimisen ja NLP:n yhdistämisen lyhyys kirjassa selittyy osin sillä, että Lindh on pitkin kirjaa eri yhteyksissä tuonut esille NLP:n periaatteita ja osin sillä, että Lindh on halunnut korostaa nimenomaan mielikuvaoppimista eikä NLP:tä. Päinvastainenkin korostus olisi kirjassa ollut mahdollinen, niin lähelle mielikuvaoppiminen ja NLP toisiinsa nähden kirjan esittelyn perusteella sijoittuvat.

\section{NLP:n nykyistä laajempi} esittely olisi osin paikannut kirjassa olevaa aukkoa sosiaalisen konstruktivismin puuttu- misesta, sillä NLP perustuu yhdeltä keskeiseltä osaltaan sosiaaliseen konstruktivismiin. Nyt kirja jää aivojen "luonnollisen" toiminnan tarkasteluun mielikuvaoppimisen kannalta. Liian yksipuolinen vetoaminen aivoihin jättää ihmisen mielikuvineen yksin ympärillä olevien objektiensa kanssa. Ihminen on kuitenkin sosiaalinen ja rakentuu ihmiseksi sosiaalisten prosessien kautta. Sosiaalisen kontekstin ja kielikuvien tarkastelu mielikuvien yhteydessä olisi avannut uusia mahdollisuuksia oppimisen tarkastelulle. Oppiminen ei varmasti tapahdu niin, että tietävä henkilö kaataa oikeita mielikuvia oppijan päähän. Oppiminen tapahtunee pikemminkin niin, että oppija vuorovaikutustilanteissa vähitellen imee itseensä oppimisympäristön tarjoamia puheita ja muokkaa oman tietoisuutensa sellaiseksi, että sen sisällä on tuon sosiaalisen verkoston tarjoama tarinasto, ohjeineen, varoituksineen ja ihanteineen. Tämä eri tilanteisiin ja konteksteihin liittyvä monimutkainen sosiaalinen koodisto toimii oppijan niin kuin muidenkin sisäisen ja ulkoisen puheen taustana.

Pauli Juuti 